\title{
Review of "Economic Spaces of Pastoral Production and Commodity Systems: Markets and Livelihoods" edited by Jorg Gertel and Richard Le Heron
}

\author{
Caroline Upton
}

\begin{abstract}
Book details
Gertel, Jorg and Le Heron, Richard (eds). Economic Spaces of Pastoral Production and Commodity Systems: Markets and Livelihoods. Farnham: Ashgate Publishing Limited; 2011. 345 pages, ISBN 978-1-4094-2531-1 (hardback), ISBN 978-1-4094-2532-8 (e-book).
\end{abstract}

Keywords: Pastoralism; Pastoral economies; Market relations; Commodity chains; Risk; Globalisation; Livelihoods

The edited volume Economic Spaces of Pastoral Commodity Production provides a welcome addition to recent debates on contemporary pastoralism, its future and transformations. It eschews a specific geographical focus to bring together case studies from across Africa, Central Asia and the former Soviet Union and, less commonly for such collections, the UK, New Zealand and Australia. The central unifying concern, as set out in the introductory chapter, is the exploration of the tensions, connections and relationships between markets and livelihoods in diverse pastoral economies. As such, it constitutes an ambitious undertaking and one that sets out to address a somewhat under-theorised area in contemporary scholarship.

The stimulus for the book came from a conference on Pastoralists and the World Market, held at the University of Leipzig in 2006, wherein participants recognised an opportunity to address persistent lacunae in understanding of pastoral systems and economies. According to the editors of this collection, these centre on the nature and extent of pastoral economic contributions, the specific articulations of pastoralist economies with world markets and the persistent emphasis on regional as opposed to comparative, global analyses of pastoral production and

Correspondence: cu5@le.ac.uk

Department of Geography, University of Leicester, University Road, Leicester LE1 7RH, UK marketing systems. The latter point emerges as a central one: the wealth of detailed, ethnographic research on specific pastoral systems and livelihoods is clearly acknowledged, but with the ambition to use such 'situated knowledges' to develop wider understandings of pastoral livelihoods and market relations. The development of a new framing, through particular attention to the markets/ livelihoods nexus, is a central claim of the book. Specifically, recent scholarship on global commodity chains and on aspects of livelihoods (such as production-consumption relations and relations of reproduction) is critiqued as presenting these as essentially separate areas of endeavour. Instead, this book argues that these strands must be brought together in order to interrogate and explain pastoralists' lived realities. There is little to disagree with here, although in themselves these scarcely seem like contentious propositions.

Prior to the empirical studies which form the core of this volume, the book offers two framing chapters: on markets as viewed from diverse theoretical perspectives (Harriss-White) and on livelihoods, with specific attention to risks and vulnerabilities attendant on market integration (Bohle). The discussion of markets as 'social and political constructs' or institutions and as socially embedded phenomena in this first framing chapter is welcome, if not especially novel, and provides a useful overview of recent approaches to the analysis of markets

\section{Springer}

(c) 2013 Upton; licensee Springer. This is an Open Access article distributed under the terms of the Creative Commons Attribution License (http://creativecommons.org/licenses/by/2.0), which permits unrestricted use, distribution, and reproduction in any medium, provided the original work is properly cited. 
from different theoretical traditions. The latter chapter by Bohle proposes an integrated framework for market risk assessment, drawing heavily on the Sustainable Livelihoods Framework and on aspects of vulnerability.

The subsequent sections of the book set out to explore and map market/livelihood intersections through case studies by multiple authors, organised according to three sections, referred to by the editors as the 'principal dynamics' in pastoral production. These are identified as (1) subsistence to market-based pastoral production, in this instance illustrated with reference solely to postcolonial Africa; (2) state-to-market-based production, examined in post-socialist contexts; and (3) the development of integrated markets linked to industrialised commodity systems. In the first section, the emphasis is on the ways in which markets (re)emerge, are sustained and transformed in often challenging contexts in countries across Africa, with varying emphasis on issues of geographical isolation, risk, conflict and globalisation, and on diverse responses between actors. For example, Wiese's work illustrates differentiated engagement with markets by cattle and dromedary herders in Chad, in isolated conditions and in the context of an emergent oil economy. Chapters by Zaal and Mahmoud highlight the ways in which market integration produces functional specialisation or diversification amongst 'traditional' pastoral households (Zaal) and strategies for mitigation of trading risks (Mahmoud) in Kenya. Komey's chapter on Sudan offers a particularly interesting and insightful analysis of market relations as an aspect of wider social relations and their transformations under conditions of conflict and civil war.

In the second section of the book, transitions from state to market relations are illustrated through case studies from Mongolia, Tibet, Western Siberia and the Pamirs. Key emergent themes include the changes in key products and trading partners attendant on the collapse of socialist era collectives and the socially differentiated consequences of these transformations (e.g. Jansen on Mongolia). The identification of new markets and products, for example, for caterpillar fungus in Tibet (Gruschke), and struggles over access to new markets and resources form another part of this story. Stammler's chapter on the transformations of the reindeer antler trade in Siberia is a particularly nice illustration of the ways in which nomadic communities may engage with global trade networks for 'new' commodities on unexpectedly favourable terms and as a way of supporting more traditional subsistence economies. It is notable, however, that these first two of the three empirical sections do have a tendency to reproduce the sort of regional focus critiqued by the editors in the introductory chapter.

The third main section, entitled 'From Commercialised Production to Integrated Markets', focuses on pastoral production and its transformations in industrialised economies and pastoral systems, namely the UK, Australia and New Zealand, with the exception of the first chapter on livestock markets and droughts in sub-Saharan Africa. The unifying theme is less clear here than that in the other sections, especially given the inclusion of Rass's chapter on Africa, although in themselves, all contributing chapters offer detailed and fascinating insights into evolving market relations under globalisation.

These three sections are illustrative of both the book's main strengths and weaknesses. Some individual studies are notable in providing especially thought-provoking insights into the specific articulations of pastoralist livelihoods and markets, and the making of market relations. Chapters by Komey, Mahmoud, Gruschke, Stammler and Gertel et al. stand out in this regard. However, despite the valuable insights offered by all chapters, the tone, emphasis and quality of the contributions are somewhat uneven, with rather limited attempts to link some of the individual chapters explicitly to the book's main themes and arguments, or to the analytical tools presented in the framing chapters. The empirical sections are also marked by limited cross-referencing between chapters by their authors; thus, the reader is given little guidance in identifying and thinking through connections and emergent themes through these sections. Undoubtedly, and as argued by the editors in the introductory chapter, this collection offers far more than a series of 'case studies put in a row...'; nonetheless, more could be done to highlight and explore unifying themes throughout the main body of the book.

The concluding chapter does, however, go some way to addressing these issues. It offers a challenging and intriguing agenda for new research, shaped by the idea of production of the book as a co-learning and politics of knowledge project, and one which gives rise to new questions about pastoralism. Through reference to contemporary strands of geographic scholarship, from Gibson-Graham's (2006) work on diverse economies to authors such as Bingham and Hinchliffe (2008) and Whatmore (2006) on human and more-than-human materialities, the authors seek to focus attention on assemblages, embodiment and risk in understanding pastoralism and pastoral economies. It is less clear, however, how this is to be achieved or what such new directions in pastoral scholarship may look like.

Overall, this book is a valuable resource for general students of pastoralism, and especially for academic researchers in this field. The detailed case studies are likely to be of more interest to the former. It remains to be seen whether the latter will take up the challenges posed in the concluding chapter - and exactly how they may chose to do so. 


\section{Competing interests}

The author declares that she has no competing interests.

Received: 8 September 2013 Accepted: 10 September 2013

Published: 04 Oct 2013

\section{References}

Bingham, N., and S. Hinchliffe. 2008. Reconstituting natures: Articulating other modes of living together. Geoforum 39(1): 83-87.

Gibson-Graham, J.K. 2006. A postcapitalist politics. Minneapolis: University of Minnesota Press.

Whatmore, S. 2006. Materialist returns: Practicing cultural geography in and for a more-than-human world. Cultural Geographies 13(4): 600-609.

\subsection{6/2041-7136-3-27}

Cite this article as: Upton: Review of "Economic Spaces of Pastoral Production and Commodity Systems: Markets and Livelihoods" edited by Jorg Gertel and Richard Le Heron. Pastoralism: Research, Policy and Practice 2013, 3:27

\section{Submit your manuscript to a SpringerOpen ${ }^{\circ}$ journal and benefit from:}

- Convenient online submission

- Rigorous peer review

- Immediate publication on acceptance

- Open access: articles freely available online

- High visibility within the field

- Retaining the copyright to your article 